\title{
Pemberdayaan Aparat Desa di Kecamatan Ketapang dan Sokobanah Kabupaten Sampang Madura
}

\author{
Gita Arasy Harwida, Mohammad Djasuli, Suyono \\ Program Studi Akuntansi Fakulta Ekonomi dan Bisnis \\ Universitas Trunojoyo Madura \\ E-mail : gita.arasy1980@gmail.com \\ http://dx.doi.org/10.21107/pgd.v4i2.4933
}

\begin{abstract}
Abstrak
Tujuan dan target khusus yang ingin dicapai dari program KKN- PPM ini adalah meningkatnya kerjasama antara perguruan tinggi, pemerintah daerah dan desa dalam mewujudkan good governance melalui program KKN-PPM dan meningkatnya kesadaran aparatur desa dan masyarakat desa untuk memperbaiki kualitas sumberdayanya dalam mengelola anggaran atau keuangan desa. Metode pelaksanaan kegiatan KKN-PPM adalah melalui penyuluhan dan pelatihan perencanaan dan pengelolaan keuangan desa dengan mengacu pada peraturan dan perundang-undangan yang ada meliputi: (i) survey pendahuluan atas kondisi aparatur dan pengelolaan keuangan desa yang telah dilaksanakan, (ii) persiapan bagi para mahasiswa sebagai pendamping atau fasilitator; (iii) pelatihan dan pendampingan disertai praktek dari aparatur desa; (iv) evaluasi program. Hasil dari kegiatan pengabdian masyarakat ini antara lain adanya proses transfer keilmuan dan pengetahuan tentang perencanaan dan pengelolaan keuangan desa akan berjalan dengan baik dengan keterlibatan berbagai pihak dalam memberdayakan aparatur desa, meningkatnya kemampuan aparatur desa, dengan adanya berbagai macam solusi untuk memecahkan permasalahannya, serta terciptanya good governance pada pemerintah desa yang mampu memberikan snowball effect kepada lapisan pemerintahan yang sejajar yaitu desa lainnya serta keluran, dan memberikan firework effect bagi pemerintahan diatasnya. Untuk hal tersebut dapat dikatakan bahwa aparat desa menjadi agent of change bagi pelaksanaan tata kelola anggaran desa.
\end{abstract}

Kata Kunci : keuangan desa, aparatur desa, perencanaan, pengelolaan keuangan

\section{PENDAHULUAN}

Kabupaten Sampang masih berstatus sebagai Kabupaten termiskin di Provinsi Jawa Timur. Walaupun Alokasi Dana Desa (ADD) dan bantuan keuangan dari Kabupaten ke desa sudah dikucurkan di setiap desa, akan tetapi penggunaannya masih belum optimal bagi pembangunan desa itu sendiri. Masih banyak dana yang digunakan oleh Kepala Desa untuk membiayai atau menutupi pembayaran Pajak Bumi dan Bangunan (PBB) bagi warganya sebagai akibat dari janji pada saat masa kampanye pemilihan Kepala Desa atau disebabkan oleh warga desa yang belum memiliki kesadaran untuk memenuhi kewajiban pembayaran PBB tersebut. Kendala lainnya adalah, masih banyak Aparatur desa yang terjebak dengan program-program kegiatan yang berulang tanpa disertai dengan analisis terhadap pencapaian program tersebut pada tahun anggaran sebelumnya dan kemampuan untuk dapat merencanakan program kegiatan yang sebenarnya dibutuhkan oleh desanya.

Kecamatan Ketapang dan Kecamatan Sokobanah di Kabupaten Sampang memiliki potensi di bidang pertanian. Para petani perdesaan di kecamatan Ketapang dan Sokobanah Kabupaten Sampang tergolong petani yang cukup produktif, ulet meskipun tertekan dalam kemiskinan. Kendala utama adalah masalah pengairan terutama pada musim kemarau, sehingga dapat dikatakan bahwa lahan pertanian lebih mengandalkan hujan sebagai sumber utama pengairannya. Sehingga, pengembangan dari sektor pertanian menjadi sangat lambat (BPS Kabupaten Sampang, 2017).

Terkait dengan permasalahan tersebut, banyak penduduk desa di Kecamatan Ketapang dan Sokobanah yang beralih profesi. Generasi senior yang dulunya hanya mengenal pertanian sebagai lahan mata pencaharian, di masa sekarang generasi mudanya banyak yang menjadi tenaga kerja Indonesia di luar negeri (TKI) atau menjadi anak buah kapal (ABK) dan berlayar ke luar negeri. Dampak dari keadaan tersebut adalah meningkatnya tingkat penghidupan sebagian masyarakat desa di Kecamatan Ketapang dan Sokobanah, terlihat dari cukup banyaknya rumah- rumah bertingkat. 
Sayangnya, hal tersebut mengakibatkan desa menjadi lengang dari kehadiran generasi muda yang potensial, dan juga, terlihat bahwa peningkatan tingkat penghidupan bagi sebagian besar penduduk tersebut belum diikuti dengan meningkatnya tingkat pendidikan, ketersediaan sarana prasarana perdesaan termasuk jalan dan pengairan yang layak.

Selain itu, Aparatur desa di Kecamatan Ketapang dan Sokobanah Kabupaten Sampang masih banyak yang berlatar belakang pendidikan menengah setingkat SMP dan SMA dan tergolong berpendapatan menengah kebawah, karena masih banyak masyarakat yang berpenghasilan cukup tidak mau menjadi Aparatur desa. Menurut Djasuli (2016), hal tersebut disebabkan tidak adanya pendapatan/gaji bagi Aparatur desa. Secara tidak langsung, keterbatasan pendidikan dari aparatur desa juga dapat mempengaruhi pemanfaatan atas danadana yang diperolehnya apabila tidak disertai dengan peningkatan pengetahuan yang mumpuni terhadap tata kelola dari penggunaan dana-dana tersebut.

Secara umum, kehidupan masyarakat di Kecamatan Ketapang dan Sokobanah merupakan masyarakat petani tradisional, namun banyak juga yang telah beralih profesi sebagai TKI di luar negeri ataupun sebagai anak buah kapal (ABK) atau berlayar. Kondisi ini menyebabkan desa-desa di Kecamatan Ketapang dan Sokobanah kehilangan banyak pemuda-pemuda yang berpotensi untuk membangun desanya walaupun mereka mampu membangun rumahrumah mewah. Di lain pihak, tingkat kemiskinan secara keseluruhan ternyata juga masih cukup tinggi. Secara umum, sarana dan prasarana di wilayah perdesaanpun masih jauh dari layak, baik itu sarana kesehatan, pendidikan, pasar, jalan dan jembatan dan lain-lain.

Menyambut diberlakukannya UU no. 6 Tahun 2014 tentang Desa, maka kapasitas aparatur desa dalam merencanakan dan mengelola anggaran bagi desanya harus lebih baik dari sekarang. Hal ini karena sumber keuangan desa tidak lagi hanya mengandalkan bagi hasil pemerintah kota/provinsi, dana perimbangan, pendapatan asli desa, ataupun bantuan serta hibah semata, melainkan akan ada alokasi dari Anggaran Pendapatan dan Belanja Negara (APBN) yang akan langsung turun ke desa (UU Desa pasal 72 ayat 1(b) dan ayat 2). Tentu saja, secara kasat mata terlihat bahwa desa-desa tersebut akan memperoleh anggaran yang lebih besar dari sebelumnya. Apalagi,
Menteri Dalam Negeri Gamawan Fauzi menyatakan bahwa setelah Peraturan Pemerintah (PP) yang mengatur implementasi dari UU Desa tersebut disahkan, maka setiap desa akan memperoleh anggaran sekitar Rp.800 juta hingga Rp.1,4 miliar per tahunnya (JPNN, 2014).

Setiap desa akan memiliki sejumlah dana yang jumlahnya cukup signifikan untuk dapat digunakan seoptimal mungkin untuk pembangunan desa tersebut baik secara fisik maupun non-fisik. Akan tetapi, tanpa didukung oleh sumberdaya manusia yang kompeten, maka akan sia-sialah anggaran tersebut (Effendi, 2008). Berbagai keterbatasan yang ada di desa, sedapat mungkin akan dapat diatasi dengan adanya anggaran desa. Sebagai contoh adalah kemampuan desa dalam mengatasi masalah kemiskinan dan meningkatkan kesejahteraan masyarakatnya melalui optimalisasi anggaran desa. Optimalisasi perencanaan dan pengelolaan anggaran desa diharapkan dapat membuka belenggu keterbatasan yang selama ini mengelilingi desa.

Keterbatasan tersebut menyebabkan desa tidak dapat melakukan inovasi- inovasi pertanian untuk meningkatkan perekonomiannya terutama di bidang pertanian sebagai mata pencaharian pokok warga desa. Hal ini disebabkan berbagai faktor diantaranya :

1. Keterbatasan Modal : mengakibatkan petani tidak mampu membeli pupuk yang harganya semakin meningkat, sehingga berakibat pada kualitas hasil panen. Selain itu keterbatasan modal ini berakibat pada akses teknologi sehingga tidak mampu mengembangkan hasil pertanian, bahan baku/bibit/benih dan sarana prasarana pertanian lainnya.

2. Rendahnya pendidikan dan pengetahuan : berakibat pada ketidakmampuan melakukan inovasi pertanian dan pemasaran hasil tani, serta lambannya penguasaan terhadap teknologi serta kurang paham masalah manajemen.

3. Rendahnya pendidikan dan pengetahuan : berpengaruh pada bagaimana penggunaan teknologi, dimana saat ini petani masih mempertahankan sistem pertanian yang tradisional. Pemasaran hasil pertanian hanya masih terbatas pada pasar desa. Sehingga ketika pada saat panen maka akan terjadi kelimpahan hasil pertanian yang berakibat pada rendahnya harga yang ditawarkan oleh para pedagang.

Disinilah peran aparatur desa dapat mengambil perannya untuk dapat mengatasi 
problematika yang terjadi didesanya. Yaitu dengan menciptakan program kerja dan kegiatan yang dapat meningkatkan kesejahteraan warga desa yang disesuaikan dengan kebutuhan desa itu sendiri. Tahap-tahap perencanaan keuangan desa harus dikuasai oleh aparatur desa untuk menghindari program kegiatan yang tidak bermakna dan tidak berguna yang mengakibatkan pemborosan angggaran dan kesia-siaan. Begitu pula, harus dikuasai kemampuan untuk mengimplementasikan semua program kegiatan yang telah direncanakan tersebut secara disiplin dan tepat waktu agar tercapai sasaran serta tujuan dari program tersebut.

Universitas Trunojoyo melalui mahasiswa KKN maupun pengabdian dosen akan memberikan pendampingan kepada aparatur desa untuk dapat melakukan proses perencanaan hingga pengelolaan keuangan desa tersebut dengan baik. Pelatihan dan pendampingan akan disesuaikan dengan kemampuan dari aparatur desa dan sumberdaya yang ada di desa tersebut. Maksudnya adalah, pendampingan akan didesain dengan metode yang sederhana, mudah dicerna dan dimengerti oleh aparatur desa namun tetap memperhatikan tujuan dari pendampingan itu sendiri. Apabila tata laksana keuangan desa ini dapat dilaksanakan dengan optimal dan baik, maka diharapkan akan terciptanya good governance dari lapisan pemerintahan terdasar yaitu desa. Harapan terbesar kami adalah bahwa penciptaan good governance yang berasal dari lapisan terdasar mampu memberikan snowball effect kepada lapisan pemerintahan yang sejajar yaitu desa lainnya serta keluran, dan memberikan firework effect bagi pemerintahan diatasnya.

Beberapa tujuan pokok dalam kegiatan pengabdian masyarakat melalui program KKN-PPM ini antara lain adalah :

1. Meningkatnya kerjasama antara perguruan tinggi, pemerintah daerah, mitra dalam mewujudkan good governance melalui program KKN PPM.

2. Meningkatkan kepedulian mahasiswa kepada permasalahan pengelolaan keuangan desa, sehingga kemampuan keilmuannya terpanggil di dalam Progran KKN-PPM ini.

3. Meningkatnya kesadaran aparatur desa dan masarakat desa untuk memperbaiki kualitas sumberdayanya dalam mengelola anggaran ataukeuangan desa serta meningkatnya kesadaran mahasiswa tentang pentingnyasebuah tata kelola yang baik dalam pengelolaan anggaran dengan turut serta melakukan pendampingan kepada aparatur desa melalui program KKN PPM.

4. Terwujudnya aparatur desa yang memiliki kompetensi mumpuni dalam melakukan perencanaan dan pengelolaan keuangan desa sehingga tercipta sebuah pemerintahan desa yang mampu mengoptimalkan keuangan desa dalam meningkatkan kesejahteraan desa melalui program kerja dan program kegiatan yang berbasis kebutuhan desa.

5. Aparatur desa mampu menyusun perencanaan untuk program dan kegiatan untuk tahun anggaran berikutnya dengan perencanaan yang berbasis kebutuhan dan berdasarkan evaluasi dari program berikutnya. Aparatur desa juga diharapkan mampu menyusun dokumen-dokumen terkait perencanaan keuangan desa.

6. Aparatur desa mampu melakukan pengelolaan keuangan desa sesuai dengan peraturan yang berlaku dan menjalankan program yang telah direncanakan secara disiplin dan tepat waktu.

\section{METODE}

Kelompok sasaran Program KKN-PPM ini adalah Aparatur Desa berada di daerah perdesaan di Kecamatan Ketapang (desa Karanganyar dan Desa Ketapang Timur) dan Kecamatan Sokobanah (desa Bira Tengah). Kelompok atau masyarakat ini akan menjadi sentra kegiatan KKN-PPM dengan harapan kegiatan akan lebih fokus dan tepat sasaran. Pada tahun sebelumnya di Kecamatan Ketapang dan Kecamatan Sokobanah Kabupaten Sampang (Desa Karanganyar, Desa Ketapang Timur dan Bira Tengah) pernah mendapatkan pendampingan dari LPPM dalam bentuk penyuluhan pertanian, manajemen desa dan pemberdayaan komunitas.

Metode pelaksanaan kegiatan KKN-PPM adalah melalui penyuluhan dan pelatihan perencanaan dan pengelolaan keuangan desa dengan mengacu pada peraturan dan perundangundangan yang ada meliputi: (i) survey pendahuluan atas kondisi aparatur dan pengelolaan keuangan desa yang telah dilaksanakan, (ii) persiapan bagi para mahasiswa sebagai pendamping atau fasilitator; (iii) pelatihan dan pendampingan disertai praktek dari aparatur desa; (iv) evaluasi program.

Pelaksanaan latihan/praktek dilakukan sebanyak 4 (empat) tahap, yaitu :

1. Survey Kapasitas Sumberdaya Aparatur

Desa : Survey pendahuluan dilakukan untuk 
mengetahui informasi terkait dengan keadaan dari aparatur pada masing-masing desa yang akan dijadikan sebagai tempat kegiatan ini.

2. Persiapan mahasiswa pendamping : Mahasiswa akan diberikan pembekalan terkait dengan materi-materi perencanaan dan pengelolaan keuangan desa berikut prakteknya. Materi yang diberikan berupa modul dan kertas kerja dan simulasi sehingga mahasiswa juga memiliki pemahaman yang komprehensif terhadap perencanaan dan pengelolaan keuangan desa.

3. Penyuluhan dan Penyadaran : Dosen pembina dan mahasiswa peserta KKN terlebih dahulu memberikan penyuluhan pendahuluan kepada aparatur desa terkait dengan keuangan desa dan pentingnya penguasaan dari para Aparatur untuk dapat melakukan perencanaan dan pengelolaan dari keuangan desa.

4. Pendampingan/konsultasi: Kegiatan ini dilaksanakan untuk memberikan pendampingan dalam menyusun perencanaan untuk tahun berikutnya dan pengelolaan keuangan desa untuk tahun berjalan. Mahasiswa akan mengalokasikan 4 jam setiap hari untuk melakukan pendampingan tersebut, sedangkan dosen pendamping akan melakukan pendampingan sekaligus monevin. Para mahasiswa dapat menentukan dan membagi peran secara mandiri untuk memenuhi kewajiban tersebut. Selama kegiatan KKN-PPM berlangsung, mahasiswa/tutor akan terus memantau dan membina kelompok sasaran sampai mereka menguasai dan terampil dalam mengaplikasikannya.

\section{HASIL DAN PEMBAHASAN \\ - Pelaksanaan Survey}

Terdapat 2 jenis survey yang dilakukan oleh tim, yang pertama adalah survey yang dilakukan untuk mendeteksi wilayah KKN PPM yang dinilai kondusif dan bersedia sebagai tempat terlaksananya KKN PPM. Sedangkan jenis survey kedua adalah untuk melakukan komunikasi intensif dengan pihak Kecamatan dan Desa terkait dengan kegiatan KKN PPM yang akan dilaksanakan di Desa tersebut. Tim tidak hanya melakukan pendekatan dengan pihak Desa, akan tetapi juga dengan Pihak Kecamatan karena beberapa hal berikut ini :

- Pihak Kecamatan mengetahui dengan seksama tentang kondisi dari seluruh desa yang ada dalam wilayah pemerintahannya.
- Pihak Kecamatan memberikan rambu-rambu agar KKN-PPM tidak mengambil lokasi pada Desa yang akan melaksanakan Pemilihan Kepala Desa (PilKades) dengan atmosfir politik yang kurang kondusif. Apalagi, topik atau tema dari KKN-PPM kami adalah pengelolaan keuangan desa, dimana saat ini sedang menjadi trending topic di Indonesia dan menjadi isu sentral ketika terjadi pemilihan Kepala Desa.

- Kecamatan memiliki fungsi pembinaan terhadap Desa-Desa yang ada dalam wilayah pemerintahannya. Termasuk didalamnya adalah dalam hal pengelolaan keuangan dari siklus perencanaan hingga pertanggungjawabannya dan pula posisi Sekretaris Desa adalah pegawai negeri sipil (PNS) dari Kecamatan.

Seluruh masukan dari Kecamatan merupakan bahan penting bagi Tim untuk menyusun strategi agar program KKN-PPM yang telah dirancang dapat dilaksanakan dengan baik. Selanjutnya Tim melakukan survey ke beberapa desa tersebut sekaligus memberitahukan bahwa akan ada program KKN-PPM disamping program KKN regular. Tidak semua desa yang disurvey tersebut bersedia untuk ditempati sebagai wahana pelaksanaan KKN-PPM karena tema pengelolaan keuangan desa masih merupakan tema yang tidak popular bahkan terkesan sensitif untuk dibicarakan. Setelah survey beberapakali dilakukan, akhirnya, terpilihlah ketiga desa yaitu desa Ketapang Timur, desa Karang Anyar, dan desa Bira Barat sebagai lokasi bagi pelaksanaan KKN-PPM dengan tema pengelolaan keuangan desa ini.

Survey pendahuluan tahap kedua dilaksanakan oleh kelompok KKN yangakan bertempat di Desa tersebut. Kelompok KKN tersebut akan menemui KepalaDesa dan aparatur desa sebagai tindak lanjut dari survei yang dilakukan oleh Tim.Selain itu, kelompok KKN juga akan mempersiapkan tempat tinggal serta fasilitasyang dibutuhkan selama program KKN dan KKN-PPM ini berlangsung. Berikutnya adalah pada saat pemberangkatan perdana KKN, sekali lagi tim KKN PPM juga turut mengawal ke desa masing-masing sekaligus melakukan dialog dengan Camat atau Sekretaris Camat dan dengan Kepala Desa. Tim KKN-PPM menjelaskan kepada pejabat terkait tersebut mengenai mekanisme pelaksanaan KKN-PPM yang akan dilaksanakan oleh mahasiswa dan oleh Tim KKN-PPM. 


\section{- Identifikasi Masalah Pasca Survey}

Ketiga lokasi desa tersebut memiliki karakter pemerintahan desa yang tidak sama. Identifikasi masalah dapat pula memetakan permasalahan pokok desa terhadap pengelolaan keuangan desanya. Berikut ini adalah hasil identifikasi masalah pada setiap lokasi:

\section{a. Desa Ketapang Timur}

Desa Ketapang Timur berada tidak jauh dari jalan utama Kecamatan Ketapang. Desa ini memiliki Kepala Desa yang telah menjabat selama 2 tahun. Kepala Desa telah mengikuti Pelatihan Pengelolaan Keuangan Desa yang diselenggarakan oleh Badan Diklat Provinsi Jawa Timur. Kepala Desa tidak memberikan begitu banyak komentar ketika tim mengemukakan tentang Program KKN PPM tetapi tidak menyatakan berkeberatan dengan program tersebut.

Setelah beberapa kali melakukan dialog dengan Kepala Desa, tim memiliki pandangan bahwa Kepala Desa ternyata tidak mengikuti pelatihan pengelolaan keuangan desa yang diselenggarakan oleh Badan Diklat Provinsi Jawa Timur dan mewakilkannya kepada Sekretaris Desa karena pada saat yang bersamaan harus berada pada acara penting lainnya. Kemudian, Kepala Desa tidak begitu dapat memberikan umpan balik ketika kami mengajak berdialog tentang bagaimana pengelolaan keuangan desa di daerahnya. Sayangnya, pada saat itu kami tidak bertemu dengan perangkat desa lainnya dan hanya Kepala Desa. Kesimpulan awal yang dapat kami berikan setelah beberapa kali survey tersebut adalah bahwa Kepala Desa memahami bahwa ia mengelola anggaran yang cukup besar akan tetapi secara teknis pengelolaan sepertinya tidak terlalu paham.

\section{b. Desa Karang Anyar}

Desa Karang Anyar terletak jauh dibagian dalam dari wilayah Kecamatan Ketapang dan berbatasan dengan Kecamatan Sokobanah. Kepala Desa sudah memasuki periode ke-2 kepemimpinannya. Sejak awal survey tim KKNPPM, Kepala Desa sudah menunjukkan antusiasme terhadap program yang akan dijalankan selama pelaksanaan KKN ini. Kepala Desa Karang Anyar tidak pernah menghadiri Diklat Pengelolaan Keuangan Desayang diselenggarakan oleh Badan Diklat Provinsi Jawa Timur dengan alasan pada saat itu ada situasi darurat di desa sehingga Kepala Desa beserta aparatur desa lainnya tidak dapat meninggalkan desa. Sambutan Kepala Desa yang cukup antusias turut meningkatkan antusiasme tim KKN PPM bahwa pelaksanaan program akan berjalan sesuai dengan yang diharapkan. Kepala Desa menjelaskan bahwa ia dan jajarannya akan berusaha untuk mengikuti seluruh aturan yang ada walaupun dengan latar belakang pendidikan yang tidak bersentuhan dengan perencanaan hingga pertanggungjawaban keuangan desa.

\section{c. Desa Bira Tengah}

Berbeda dari kedua desa sebelumnya, Desa Bira Tengah berada dalam wilayah Kecamatan yang berbeda yaitu Kecamatan Sokobanah. Desa ini adalah sasaran terbaru setelah Desa sasaran sebelumnya dinilai tidak kondusif untuk dijadikan tempat pelaksanaan program KKN PPM dengan tema pengelolaan keuangan desa. Desa Bira Tengah menjadi lokasi terjauh karena Kecamatan Sokobanah terletak setelah Kecamatan Ketapang.

Tim KKN-PPM memperoleh rekomendasi dari aparatur Kecamatan bahwa Desa Bira Tengah dapat dijadikan sebagai lokasi pelaksanaan KKN-PPM. Setelah melakukan beberapa kali survey, tim menemukan adanya keunikan tersendiri di Desa ini. Kearifan lokal masih sangat kental dan ternyata juga sangat mempengaruhi situasi pemerintahan desa.

Hasil survey Desa Bira Tengah menunjukkan bahwa posisi kekosongan kekuasaan sebenarnya tidak mengganggu jalannya pemerintahan desa karena Plt. Kepala Desa dapat berkomunikasi dengan baik dengan Kepala Desa serta seluruh aparat desa. Hal ini terlihat bahwa Plt.Kepala Desa masih berada di Kecamatan untuk melaksanakan pelayanan kepada warga walaupun jam sudah menunjukkan jam 2 siang. Begitupun,

kami diantar untuk menemui Kepala Desa (de facto) dan mendiskusikan pelaksanaan program KKN-PPM. Secara eksplisit Kepala Desa menyatakan tidak hadir dalam Diklat pengelolaan keuangan desa yang diadaakan oleh pemerintah Provinsi Jawa Timur karena diwakilkan pada Sekeretaris Desa, namun menyambut baik apabila akan ada pembinaan pengelolaan keuangan desa melalui program KKN-PPM.

\section{Monitoring Pelaksanaan Pendampingan Mandiri}

Sebelum pelaksanaan KKN, seluruh peserta telah memperoleh bimbingan teknis prapemberangkatan. Akan tetapi, bagi peserta KKN yang berasal dari Fakultas Ekonomi telah pula 
diberikan pengarahan secara khusus terkait materi pengelolaan keuangan desa dan teknis pelaksanaan pendampingan ketika di lapangan. Mahasiswa akan melakukan penelusuran pelaksanaan pengelolaan keuangan desa, mengumpulkan kopi dari dokumen-dokumen pengelolaan desa untuk dipelajari, dan melakukan pengamatan serta pendampingan pada saat aparatur desa melaksanakan tugas terkait dengan pengelolaan keuangan desa. Hal tersebut ternyata tidak semudah yang diperkirakan sebelumnya. Walaupun kegiatan ini sudah memperoleh ijin dan dukungan dari pejabat terkait, akan tetapi aparatur desa tidak memiliki jadwal yang tetap dalam melaksanakan pengelolaan keuangan desa. Hal tersebut ternyata terjadi karena aparatur desa tidaklah sama dengan petugas kelurahan yang berkantor dengan jam kerja tertentu. Aparatur desa, kecuali Sekretaris Desa, adalah warga desa yang diberikan kepercayaan oleh Kepala Desa untuk membantu jalannya pemerintahan desa dan memiliki pekerjaan tetap yang berbeda-beda. Sehingga, mahasiswa membutuhkan beberapa kali melakukan pendekatan dan kunjungan kepada aparatur desa yang berwenang. Selain didampingin tim KKN PPM, peserta juga didampingi dan dibimbing oleh Dosen Pembimbing Lapangan (DPL) yang juga memiliki

kemampuan pada bidang manajemen pengelolaan keuangan desa. Sebelum penyuluhan diselenggarakan, tim KKN-PPM melaksanakan monitoring terhadap pelaksanaan KKN-PPM oleh mahasiswa. Pada setiap desa ditemukan fenomena yang hampir sama dan tidak cukup menggembirakan. Hasil dari monitoring tersebut adalah :

- Dokumen Perencanaan seperti RPJMDes, RKPDes, dan APBDes tidak sepenuhnya disusun oleh aparatur desa.

- Tidak semua Kepala Desa memahami peran dan tugasnya dalam mengelola Keuangan Desa. Penelusuran menunjukkan bahwa seluruh dokumen disusun oleh petugas dari Kecamatan walaupun proses penyusunan tetap melibatkan aparatur desa.

- Tidak hanya dokumen perencanaan, dokumen penatausahaan dan pertanggungjawaban juga masih menggantungkan penyusunannya kepada petugas Kecamatan. Bendahara Desa dan aparatur desa lainnya lebih ke fungsi pencatatan kas masuk dan kas keluar.

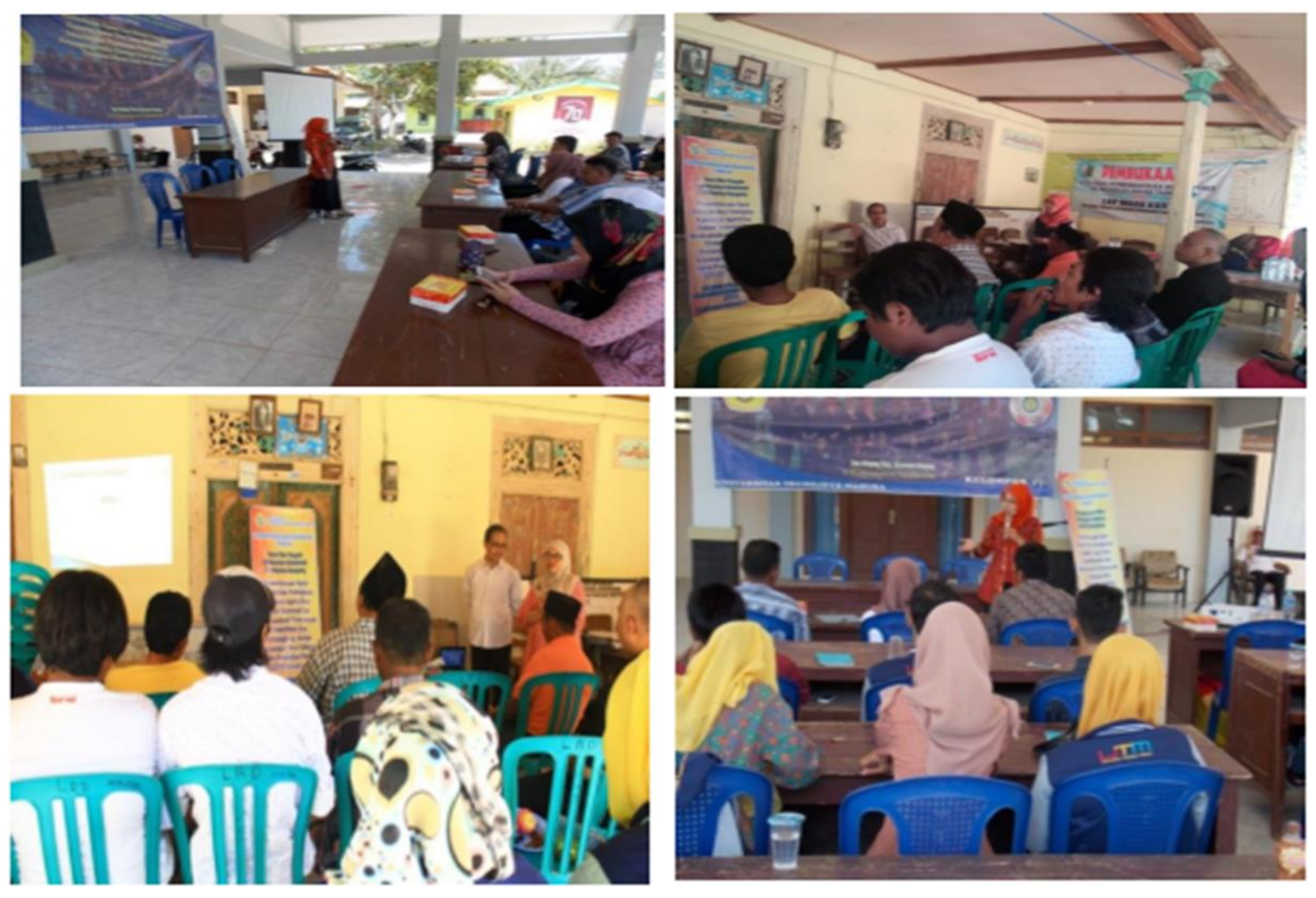

Gambar 1. Proses Pendampingan Aparat Desa 


\begin{abstract}
Peserta KKN tetap melaksanakan pendampingan dan penyuluhan tentang bagaimana seharusnya pengelolaan keuangan desa dilaksanakan. Berdasarkan penelusuran peserta KKN dan dokumen yang berhasil dikumpulkan, tim KKN-PPM menjadwalkan untuk melaksanakan penyuluhan dengan memberikan materi kepada aparatur desa dan petugas dari Kecamatan yang selama ini memberikan bantuan untuk menyusun dokumendokumen pengelolaan keuangan desa dan melakukan review terhadap dokumen-dokumen tersebut.
\end{abstract}

\section{Pelaksanaan Penyuluhan Bagi Aparat Desa}

Penyuluhan bagi Aparatur Desa dilaksanakan pada minggu ke 3 dari pelaksanaan KKN setelah tim dan peserta KKN mempelajari seluruh dokumen, hasil survey, dan hasil wawancara dengan aparatur desa dan aparatur kecamatan. Melihat dari hasil tersebut, tim KKN memutuskan untuk memberikan materi yang menitikberatkan pula pada pembangkitan kesadaran kepada aparatur desa tentang pentingnya pemahaman terhadap pengelolaan dana desa. Terutama jika dilihatdari tanggungjawab dan resiko yang harus dihadapi apabila ditemukan ketidakpatuhan hingga kecurangan atas pengelolaan tersebut.

Selain itu, kami juga menitikberatkan bahwa kemampuan aparatur desa dan masyarakat desa dalam merencanakan pembangunan desanya akan dapat memakmurkan desa itu sendiri, yaitu dengan memaksimalkan potensi yang dimiliki desa dan kesempatan yang dimiliki desa untuk dapat melakukan optimalisasi terhadap potensi tersebut. Sedangkan bagi petugas Kecamatan kami memberikan penyuluhan agar fungsi pembinaan tidak berubah menjadi memanjakan dengan terus menerus membuatkan seluruh dokumen tersebut. Karena apabila petugas kecamatan yang menyusunkan dokumen pengelolaan keuangan desa, maka fungsi pembinaan ataupun fungsi pengawasan dari kecamatan akan luntur. Kami menegaskan bahwa apabila good governance dapat diwujudkan pada tata kelola keuangan desa, maka akan terwujud masyarakat desa yang mandiri dan tentunya akan memberikan efek domino yang baik bagi tata kelola pemerintah di atasnya hingga ke pemerintah pusat. Nah, disinilah peran agent of change dari aparatur desa tersebut terwujud. Penyuluhan ini dilaksanakan serentak di 3 desa dengan pemateri yang sudah memiliki sertifikat Training of Trainer (TOT) manajemen pengelolaan keuangan desa dari Ikatan Akuntan Indonesia Jawa Timur sebagai mitra dari Pemerintah Provinsi Jawa Timur.

\section{KESIMPULAN}

Berdasarkan hasil kondisi riil dilapangan terhadap pelaksanaan kegiatan KKN-PPM dapat disimpulkan bahwa:

1. Selama ini, penyusunan dokumen pengelolaan keuangan desa masih lebih banyak ditangani oleh petugas Kecamatan karena aparatur desa masih kesulitan untuk dapat melaksanakan secara mandiri.

2. Dengan diberlakukannya UU Desa, Kepala Desa dan aparatur desa sudah mulai menyadari bahwa peran dan tanggungjawab mereka semakin besar dan harus segera untuk dapat berbenah diri dan mulai untuk menerapkannya.

3. Akan tetapi, hal tersebut masih membutuhkan proses yang harus lebih didukung lagi oleh pemerintah daerah dan praktisi akademisi dari perguruan tinggi serta dari masyarakat.

Adapun saran yang dapat diberikan setelah berlangsungnya kegiatan pengabdian masyarakat ini adalah :

1. Kegiatan pengabdian semacam ini masih perlu untuk ditindaklanjuti dan ditingkatkan frekuensinya, karena sifatnya yang khusus dan fokus hanya pada beberapa desa dapat memberikan efek yang lebih mendalam bagi jajaran aparatur desa dan masyarakat desa.

2. Melalui program pendamping desa yang disiapkan oleh Kementerian Desa dan DT, pemerintah harus menyiapkan pendamping desa yang kompeten.

\section{DAFTAR PUSTAKA}

Badan Pusat Statistik. 2017. Sampang dalam Angka. Sampang.

Djasuli, M. 2016. Pengembangan Model LKMS (Lembaga Keuangan Mikro Syari'ah) dengan Pola Grameen Bank dalam Upaya Penguatan Ekonomi Masyarakat Petani Garam di Pulau Madura. Laporan Penelitian. LPPM UTM. Bangkalan.

Efendi, L. 2008. Usaha usaha Pemberdayaan Masyarakat. Penerbit Insani. Malang. 
46 Jurnal Pangabdhi 